\title{
Pragmatic features of audiovisual translation
}

\section{Dilnozakhon SHERMUKHAMEDOVA ${ }^{1}$}

Tashkent State University of Economics

\begin{tabular}{l} 
ARTICLE INF0 \\
\hline Article history: \\
Received October 2021 \\
Received in revised form \\
15 October 2021 \\
Accepted 20 November 202 \\
Available online \\
15 December 2021 \\
\hline Keywords: \\
audiovisual translation, \\
film, \\
dubbing, \\
subtitling, \\
voiceover, \\
film translation, \\
cinema language, \\
audio description.
\end{tabular}

\begin{abstract}
The article discusses the peculiarities of translation of audiovisual content and the concept of audiovisual translation, its varieties, as well as the originality of translation. Moreover, the article analyzes domestic and foreign research experience in line with audiovisual translation, separate approaches to the study this type of translation, the positive and negative aspects of each of the considered approaches are evaluated. The author examines in detail the text-centric approach to the study of audiovisual translation, concludes that its futility, opposing this approach to more developed in foreign translation studies functional, communicative-functional, descriptive-semiotic, linguocultural and integrative-interdisciplinary approaches.

2181-1415/@ 2021 in Science LLC.

DOI: https://doi.org/10.47689/2181-1415-vol2-iss11/S-pp181-186

This is an open access article under the Attribution 4.0 International (CC BY 4.0) license (https://creativecommons.org/licenses/by/4.0/deed.ru)
\end{abstract}

\section{Audiovizual tarjimaning pragmatik xususiyatlari}

\author{
Kalit so'zlar: \\ audiovizual tarjima, \\ film, \\ dublyaj, \\ subtitrlash, \\ ovoz berish, \\ film tarjimasi, \\ kino tili, \\ audio tasvirlash.
}

\section{ANNOTATSIYA}

Ushbu maqolada audiovizual kontentni tarjima qilish xususiyatlari va audiovizual tarjima tushunchasi, uning turlari, shuningdek, tarjimaning o'ziga xosligi ko'rib chiqiladi. Bundan tashqari, maqolada audiovizual tarjima sohasidagi mahalliy va xorijiy tadqiqot tajribasi tahlil qilinadi, tarjimaning ushbu turini o'rganishga individual yondashuvlar baholanadi, ko'rib chiqilayotgan har bir yondashuvning ijobiy va salbiy tomonlari o'rganiladi. Muallif audiovizual tarjimani o'rganishda matn markazli yondashuvni atroflicha ko'rib chiqadi, uning besamar ekanligi, bu yondashuv xorijiy tarjimashunoslikda yanada rivojlangan funksional, kommunikativ-funksional, tavsifsemiotik, lingvomadaniy va integrativ-fanlararo yondashuvlarga qarshi chiqadi, degan xulosaga keladi.

\footnotetext{
${ }^{1}$ Senior teacher, the English language department, Tashkent State University of Economics. Tashkent, Uzbekistan. E-mail: noz_1983@mail.ru.
} 


\section{Прагматические особенности аудиовизуального перевода}

\author{
Ключевые слова: \\ аудиовизуальный \\ перевод, \\ фильм, \\ дубляж, \\ субтитры, \\ закадровый голос, \\ перевод фильма, \\ язык кино, \\ аудиоописание.
}

\begin{abstract}
АННОТАЦИЯ
В статье рассматриваются особенности перевода аудиовизуального контента. В особенности, варианты аудиовизуального контента, его разновидности, в привязке к смысловому варианту. На оригинальность перевода влияют многие факторы. В статье анализируется отечественный и зарубежный опыт исследований в области аудиовизуального перевода. Рассматриваются различные варианты переводаа. Кроме этого, данные подходы к изучению оцениваются положительные и отрицательные стороны каждый из рассмотренных подходов. Автор исследует текстоцентрический подход в исследовании. Анализирует аудиовизуальный перевод, который приводит к выводу о его перспективности. Данный подход противоречит более развитым функциональным, коммуникативно-функциональным и описательносемиотическим, лингвокультурным подходам. Исследуются интегративно-межуказанные методы, применительно к требованиям зарубежных научных изданий.
\end{abstract}

In recent years, the problems of theory and practice of translation have attracted more and more attention from the academic community and practitioners. Increasingly, the issues of quality assurance of translation services, the development of a methodology for teaching translation, and the search for ways of effective interaction in the "translatorcustomer" pair are being raised. In general, a modern approach to the problems of translation as a process translation activity, as a result, necessitated the formation of new methodologies for studying the phenomenon of translation. In this regard, it is especially important to study domestic and foreign research experience, identify the main trends and approaches to identifying patterns of various types of translation [1].

Audiovisual translation is gaining more and more popularity in the world, and this is not surprising, since every year studios, TV channels and individuals generate a huge amount of audiovisual content. Billions of hours of cartoons, TV series, feature films and documentaries, commercials and other audiovisual products translated into different languages. Quite often, such a translation is not high quality [3]. This is due to several factors: the complexity of the technology of the audiovisual translation and dubbing process content, the entry into the market of a large number of "fan" studios and amateur translators, as well as insufficient elaboration of the theoretical foundations of audiovisual translation. In this research concentrate on the last factor, aiming to study and summarize domestic and foreign experience, research in the field of audiovisual translation, and based on the data obtained, formulate the main approaches to the study of this phenomena $[2,6]$.

The term "audiovisual translation" entered linguistics and translation studies relatively recently. In most cases, domestic works of a theoretical and applied nature are devoted to the study of film / video translation as a special type of translation film translation activities, which automatically removes from the scope scientific interests a significant amount of audiovisual content: commercials, theatrical performances, games, talk shows, etc. 
Term "Film / video translation" is considered a hyponym in relation to the term "Audiovisual translation" and is used to refer to the process on "literary interlanguage processing of the content. Communication Theory that editing sheets with the subsequent rhythmic laying of the transfer text and its dubbing or introduction into the video sequence in the form of subtitles" $[3,4]$. In this case, the translation of films is considered as a translation of the text, which does not take into account the specifics of the film text, namely its polysemioticity (in some works the terms "polycode" and "creolized text" are used). The perception of the translation of audiovisual products as a translation of literary, artistic, hinders the understanding of the essence of this type of translation, in which other semiotic systems have a significant impact on the result, firmly connected with the textual component of the film: visual syntax, video sequence, noise and music series, significant inscriptions, etc. The translation of the verbal component of the polysemiotic unity of an audiovisual work, as a result of which a new verbal component of this unity is created, suitable for further processing (subtitling, dubbing, localization, etc.), taking into account the general context of the work, the expected response of the consumer of the content, and functional limitations imposed by each separate type of further processing.

It should be noted that the surge of interest in the problems of audiovisual translation (multimedia translation, film translation, film / video translation, etc.), when domestic researchers realized that for studying the translation of audiovisual materials, it is necessary to use a separate methodological apparatus, different from what is traditionally used in the study of interpretation or translation. However, the text-centered approach to translation in general, within which the translation is analyzed exclusively from a linguistic standpoint, has left its imprint on the results of a large number of studies [5].

One of the first problems of audiovisual translation began to study V.E. Gorshkova [4], considering audiovisual translation from the perspective of its linguistic, semiotic and linguo cultural features. His work devoted to the study of the translation of film dialogue, the researcher provides a unified model of translation, in which film dialogue is considered as a combination of the following components: speaker, meaning, transmission channel and original receptor. Accordingly, having passed through the translator, the film dialogue is transformed in accordance with the above components and the specificity of receptor linguaculture the target language [4]. In this case, the author does not take into account the peculiarities of technical limitations associated with various types of translation (dubbing, subtitling, voice-over translation, audio description, etc.), as well as the primacy of the video sequence over the text. In fact, the entire fabric of an audiovisual work is divided into two separate layers: cinematic text as a complex polycode and multi-level semantic unity and cinematic dialogue as the verbal component of the film. From a similar point of view, translation of a film dialogue is considered in the work of M.S. Snetkova, dedicated to the linguistic and stylistic aspects of translation of Spanish film texts [3]. In the aspect of cultural transfer consider audiovisual translation by I.K. Fedorov, focusing on the additional communicative load that the microstructures of the original language receive within the macrostructure of the original culture. The technology of translation is presented to the author as a set of translation techniques used within the strategy of pragmatic adaptation of the original in situations "when both cultures know the same referent, but different meanings are used in the working languages of the translation" [1]. The author does not install the choice dependencies, methods of adaptation from the type of audiovisual translation being carried out, considering the translation of film and video 
materials as a kind literary translation. On the other hand, the author admits that some of the components of culturally significant information can be explicated in the video sequence of an audiovisual work, which makes it possible to "remove" a part of the linguocultural load from the translator and the recipient of the translation.

Within the framework of the linguo cultural approach to the study of audiovisual translation, R.A. Matasov, who pays special attention to the history of the development of cinema and film / video translation, as well as the extralinguistic conditioning of this type of translation. It is interesting that in his work the researcher moves away from the textocentric approach, arguing that "the subject of film / video translation is the linguistic system of the film text, which is inseparably semantic connection with the components of the non-linguistic system included in its composition ..." [7]. The author analyzes in detail the main difficulties of this type of translation, caused by the linguistic and extralinguistic aspects of film / video translation, linking them with the peculiarities of the film language and the type of translated film text. Particular value is the section devoted to the didactics of film / video translation, in which the author formulates the goals and structure of the course for this translation, develops exercises and assignments for students.

The gradual change in views on audiovisual translation, conditioned by the entry into the "research arena" of practitioners, has led to the fact that in the majority of works over the past few years, the film text is considered not in isolation from the rest of the context of the film, but as a polysemiotic unity. It is necessary to note the article by $\mathrm{O} . \mathrm{Yu}$. Kustova, who considers the polycode nature of an audiovisual text as a starting point in building a translation strategy for such a text. The author notes the phenomenon of the unity of the verbal and non-verbal components of the film text, and the audiovisual itself, the work appears as a kind of collection of different codes with the aim of producing a certain emotional and aesthetic impact on the recipient. The author sees the cultural integration of the elements of the polycode text as the key to the success of the perception of the film text and, accordingly, its translation [5]. The researcher considers audiovisual translation as a special type of translation activity that requires the development of separate research and teaching methods. During the development of practical recommendations for teaching audiovisual translation, the author points not only to the polysemantic and polycode nature of an audiovisual work, he rightly states that "an audiovisual translator must take into account not only linear and sequentially processed semantic context speech, but also some supra-verbal integral visual and semantic constructs"[6]. The author emphasizes that audiovisual translation is a limited translation, and the availability and type of restrictions depends on the type of translation performed (translation for voiceover, two-dimensional or three-dimensional subtitling, translation for dubbing), target audience of translation recipients, level of interaction streams of information intertwined in an audiovisual context.

This approach is inherently different from the textocentric, purely linguistic approach, and can be characterized as pragmatic-dynamic, taking into account the need to make a certain impact on the recipients of the entire complex of audiovisual works in which the text is only one of the components.

As a result of globalization, the penetration into our lives of new sources of information consumers of audiovisual works - spectators, distributors - make rather high demands on the quality of translation of audiovisual products. On the other hand, a huge number of new types of audiovisual works are emerging. The transmedia projects that 
exist simultaneously on several platforms are becoming fashionable, more and more often viewers prefer to watch films, series and TV shows using mobile devices, changes in the field of legislation pose new challenges for audiovisual translators, for example, the need to master those types of translation for people with disabilities: audio descriptions, creating overtitles to accompany theatrical performances, creating subtitles for hearing impaired audiences. It is noting that more and more often it is not just about translating an audiovisual work, but about its localization and transcription [8]. And all these processes require theoretical comprehension, the development of a strategy for the implementation of new types of translation, the development of skills in working in new conditions, the development of innovative methods of teaching audiovisual translation.

When translating for full dubbing (lip-synq), it is very important to synchronize lip movements and the phonetic image of the translated text. Translation quality is assessed based on how well the translator "put the text on his lips". The translator is forced again to synthesize text based on parallel meanings, recreating semantic integrity of text and images within another language and culture [7]. Dubbing the film, the translator does not translate words or even meanings as such, but the emotional component of the work to fit into the timing of the replica in the original language. When dubbing a cartoon, for example, it is not. However, in the cartoon, you need to try to get into syllable closures - when the hero opens and closes his mouth; therefore it is necessary that the translated version has the same original number of syllables. With lipstick to translate one film takes one to two weeks. When translating for 3D subtitling translator faces the fact that "the semantic components of speech and image are inextricably fused, since all elements of the film language (including 3D subtitles) are equally responsible for creating the illusion of threedimensional realism of an audiovisual work, or games" [6].

At the moment, translation studies, in contrast to foreign, take only the first steps towards understanding the phenomenon of audiovisual translation and research. Into its features and patterns. There is still an opinion that audiovisual translation is not a special type of translation activity, but just a kind of oral or literary translation. Analysis of the approaches to the study of this phenomenon, developed by foreign colleagues, once again convinces me that this is not the case. In this regard, asserting the need to develop a domestic paradigm for the study of audiovisual translation, conduct empirical research in line with descriptive translation studies, in which the main approaches to the translation of audiovisual products into native language, studying the features of the translation of audiovisual works intended for demonstration using various platforms (TV, cinema, DVD, mobile devices, etc.), features translation of works of various genres, problems of creating a soundtrack commentary and audio description, etc. The translation studies have more questions about audiovisual translation than answers. However, this fact reveals broad prospects for both beginners and experienced researchers who love audiovisual translation and want to make their own contribution to the development of the world practice of studying this amazing and unusual phenomenon. 


\section{REFERENCES:}

1. Chaume F. Synchronization in dubbing. A translational approach // Topics in audiovisual translation / Ed. by P. Orero. Amsterdam; Philadelphia: John Benjamins Publ. Co, 2004. - PP. 35-52.

2. Delabastita D. Translation and mass-communication: Film and T.V. translation as evidence of cultural dynamics // Babel. 1989. - Vol. 35(4). - PP. 193-218.

3. Díaz Cintas J. Clearing the Smoke to See the Screen: Ideological Manipulation in Audiovisual Translation // Meta. 2012. - Vol. 57, - № 2. - PP. 279-293.

4. Gorshkova V.E. Film translation: dubbing vs. subtitles (based on the film Luc Besson "Angel", France, 2005) // Bulletin of NSU. Series: Linguistics and Intercultural Communication. 2007.Vol. 5, - № 1. - PP. 133-140.

5. Kozulyaev A.V. Audiovisual polysemantic translation as a special form translation activities and features of teaching this type of translation.

6. Kustova O.Yu. Polycode text as a factor in film translation strategy // Actual directions of scientific research: from theory to practice.

7. Maleonova E.D. The materials of the Intern. scientific. conf. Apr 23-24, 2013 SPb., 2013. - PP. 374-381.

8. Matasov R.A. Translation of film / video materials: linguocultural and didactic aspects: dis. ... Cand. philol. sciences. M., 2009. - P. 211. 